IP $\rightleftharpoons$ B

\title{
First record of Caliothrips phaseoli (Hood, 1912) (Thysanoptera: Thripidae) in Apuleia leiocarpa (Fabaceae) seedlings in Rio Grande do Sul, Brazil
}

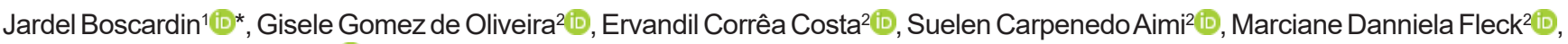 \\ Maristela Machado Araujo ${ }^{2}$ (D)
}

${ }_{1}^{1}$ Universidade Federal de Uberlândia, Rodovia LMG 746, km 1, Araras, CEP 38500-000, Monte Carmelo, MG, Brazil

Universidade Federal de Santa Maria, Avenida Roraima, n 1000, Camobi, CEP 97105-900, Santa Maria, RS, Brazil

\author{
*Autor correspondente: \\ jardel.boscardin@ufu.br \\ Index terms: \\ Forest entomology \\ Seedling \\ Thrips \\ Termos para indexação: \\ Entomologia florestal \\ Mudas \\ Tripes
}

Received in 12/04/2018

Accepted in 24/05/2019

Published in 12/12/2019

\begin{abstract}
Resumo - This study aimed to register the occurrence of phyllophagous insects attacking seedlings of Apuleia leiocarpa (Vogel) J. F. Macbr. (grapia), a native species to Brazil, which is on the red list of endangered native flora in Rio Grande do Sul State. In February 2012, adults of the pest Caliothrips phaseoli were identified causing damage to the leaves of 168 two-year-old grápia seedlings (mean stem diameter $=2.3 \mathrm{~cm}$; mean height $=22.5 \mathrm{~cm}$ ) in Santa Maria, RS. This is the first record of the occurrence of Caliothrips phaseoli in Apuleia leiocarpa seedlings in Brazil.
\end{abstract}

\section{Primeiro registro de Caliothrips phaseoli (Hood, 1912) (Thysanoptera: Thripidae) em mudas de Apuleia leiocarpa (Fabaceae) no Rio Grande do Sul, Brasil}

\begin{abstract}
O objetivo desse trabalho foi registrar a ocorrência de um inseto filófago atacando mudas de Apuleia leiocarpa (Vogel) J. F. Macbr. (grápia), espécie nativa do Brasil, que se encontra na lista vermelha de espécies da flora nativa ameaçadas de extinção no Rio Grande do Sul. Em fevereiro de 2012, foram identificados os adultos do inseto-praga, Caliothrips phaseoli, causando injúrias em folhas de 168 mudas de grápia, com dois anos de idade (diâmetro médio do coleto $=2,3 \mathrm{~cm}$ e altura média $=$ $22,5 \mathrm{~cm}$ ) em Santa Maria, RS. Este é o primeiro registro da ocorrência de Caliothrips phaseoli em mudas de Apuleia leiocarpa no Brasil.
\end{abstract}

Apuleia leiocarpa (Vogel) J. F. Macbr. (Fabaceae), popularly known in Brazil as grapia, is a native species that occurs naturally in Brazil between the latitudes of $1^{\circ} 25^{\prime} \mathrm{S}$ in Pará and $31^{\circ} 50^{\prime} \mathrm{S}$ in Rio Grande do Sul. The species is notable for producing round and sawn timber. It is used for beekeeping and for medicinal and landscape purposes, as well as for the recovery and restoration of degraded environments (Carvalho, 2003).

Grapia is on the red list of endangered native flora of Rio Grande do Sul State and it is classified as critically endangered. This means that the species is facing an extremely high risk of extinction (Rio Grande do Sul, 2014). Therefore, studies on the propagation of $A$. leiocarpa are very important. Among the limiting factors for producing quality seedlings are pest species, which can compromise germination, planting, and seedlings growth and future trees.

Pest species associated with grapia seeds in Brazil are: Ormiscus vulgaris Jordan, 1904 (Coleoptera: Anthribidae); Acanthoscelides ambopygus Kingsolver, 1982; A. bilobatus Kingsolver, 1982; A. unguiculatus Kingsolver, 1982 (Coleoptera: Chrysomelidae); and 

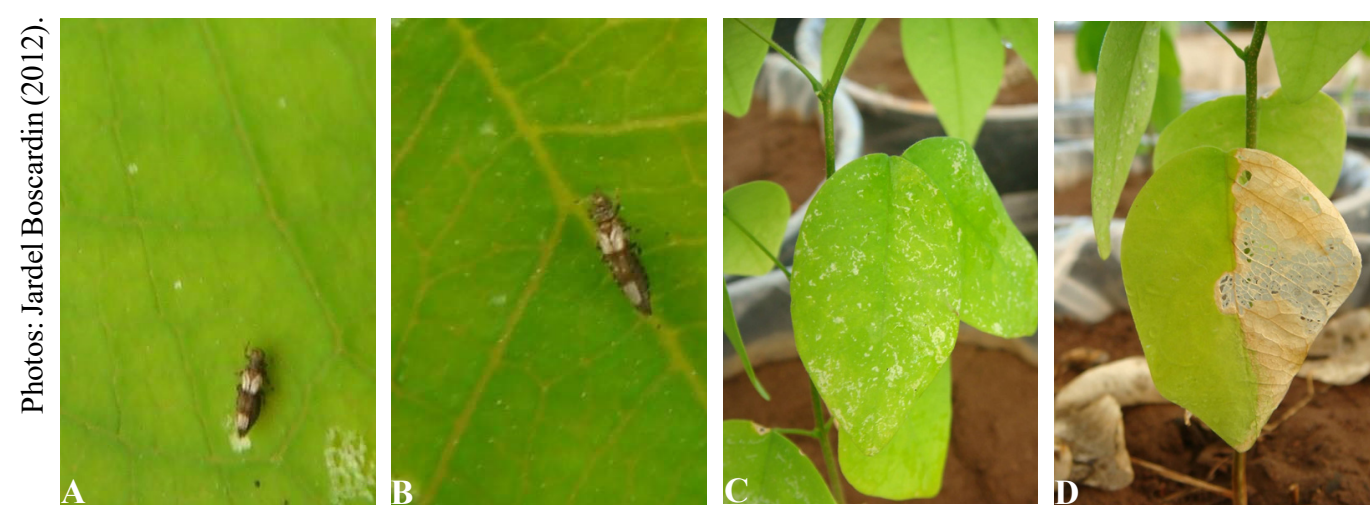

Figure 1. Caliothrips phaseoli adults (A, B); damage caused to Apuleia leiocarpa seedlings (C, D).

Lophopoeum sp. (Coleoptera: Cerambycidae) (Santos et al., 1989). Loureiro et al. (2004) also reported the species A. ambopygus, A. bilobatus (Coleoptera: Chrysomelidae), and Lophopoeum timbouvae Lamare, 1982 (Coleoptera: Cerambycidae) in grapia seeds, with the latter causing damage.

Despite reports of insects associated with grapia and other forest species (mainly native ones), little is known about the pest species that attack plants during the nursery phase. Therefore, the present study aimed to report the first occurrence of Caliothrips phaseoli (Hood, 1912) (Thysanoptera: Thripidae) on grapia seedlings in the central region of Rio Grande do Sul State, Brazil. The study was carried out at the Viveiro Florestal of the Departamento de Ciências Florestais of the Universidade Federal de Santa Maria, located at coordinates $29^{\circ} 43^{\prime} 15^{\prime \prime} \mathrm{S}$ and $53^{\circ} 43^{\prime} 19^{\prime \prime} \mathrm{W}$. The municipality of Santa Maria is located in the physiographic region of the Central Depression in Rio Grande do Sul, at a minimum altitude of $130 \mathrm{~m}$ a.s.1. According to Köppen classification, the climate of the region is Cfa (subtropical humid), with an average temperature in the coldest month between $-3{ }^{\circ} \mathrm{C}$ and $18{ }^{\circ} \mathrm{C}$, and hot summers averaging $>22{ }^{\circ} \mathrm{C}$ for the hottest month, and precipitation $>40 \mathrm{~mm}$ in the driest month (Alvares et al., 2013).

The study took place in February 2012 using 168 60 -months-old grapia seedlings, with a mean stem diameter of $2.3 \mathrm{~cm}$ and mean height of $22.5 \mathrm{~cm}$. The adult insects that were causing damage to the plants were collected and sent for identification to Adriano Cavalleri of the Universidade Federal do Rio Grande, Instituto de Ciências Biológicas, where the specimens were deposited in the Laboratório de Entomologia,
Sistemática e Biogeografia. In total, 40 adult specimens of C. phaseoli (Figures 1A and 1B) were collected. They were found causing damage to the leaves of A. leiocarpa seedlings (Figures 1C and 1D). It should be noted that all 168 seedlings were inspected and were found to be infested by $C$. phaseoli.

C. phaseoli are phyllophagous and are therefore usually found on leaves or flowers feeding off the sap. The damage (perforations and subsequent fall) caused to the leaves of $A$. leiocarpa (Figures 1) resulted from $C$. phaseoli feeding producing obvious lesions. This species reproduces by amphigonia and parthenogenesis with exclusively male offspring in the latter case (Sosa et al., 2017).

Few Thysanoptera species are reported in the country as being economically or ecologically important pests for seedlings and trees. However, C. phaseoli is an important pest for several crops, and has been reported on the economically important Moringa oleifera (Moringaceae) in México (Molina-Arjona et al., 2018). This species preferentially feeds on Fabaceae species, such as Phaseolus vulgaris L. (common bean), Glycine $\max$ (L.) Merr (soy), Pisum sativum L. (peas) and Arachis hypogaea L. (peanut), among others. There are also records of them feeding on Apocynaceae and Convolvulaceae leaves (Silva et al., 1968). Studies on Brazilian species have mainly focused on $P$. vulgaris (Jesus et al., 2010; Souza et al., 2012; Boiça Júnior et al., 2015) and G. $\max$ (Lima et al., 2013; Toldi et al., 2016). The species has also been reported on Mentha sp. (mint) leaves of the family Lamiaceae (Lima et al., 2016) and on weeds (Lima \& Zucchi, 2016), in Brazil.

Botanical insecticides can be used for the control of C. phaseoli in the nursery. An application of Azadirachta 
indica A. Juss. (neem tree) oil in conjunction with insecticide use could reduce $C$. phaseoli infestation (Jesus et al., 2009). The use of aqueous extracts from green fruits, branches, and leaves of Melia azedarach L. (chinaberry tree) also seems promising for controlling C. phaseoli (Dequech et al., 2011).

\section{Conclusion}

This is the first record of the occurrence of Caliothrips phaseoli infesting Apuleia leiocarpa seedlings in Rio Grande do Sul State, Brazil. It is necessary to study the population dynamics of $C$. phaseoli and to quantify the possible damages caused in A. leiocarpa seedlings.

\section{References}

Alvares, C. A. et al. Köppen's climate classification map for Brazil. Meteorologische Zeitschrift, v. 22, n. 6, p. 711-728, 2013. http:// dx.doi.org/10.1127/0941-2948/2013/0507.

Carvalho, P. E. R. Grápia. Colombo: Embrapa Florestas, 2003. 15 p. (Embrapa Florestas. Circular técnica, 77). http://www.infoteca. cnptia.embrapa.br/infoteca/handle/doc/314140.

Dequech, S. T. B. et al. Atividade inseticida de extratos de meliáceas sobre Phaseoli caliothrips Hood, 1912 (Thysanoptera: Thripidae) em cultivos em estufa plástica. Revista da FZVA, v. 18, n. 1, p. 68-77, 2011.

Jesus, F. G. de et al. Infestação de Bemisia tabaci biótipo B e Caliothrips phaseoli em genótipos de feijoeiro. Bragantia, v. 69, n. 3, p. 637-648, 2010. http://dx.doi.org/10.1590/S000687052010000300016.

Jesus, F. G. de et al. Infestation of Caliothrips phaseoli (Thysanoptera: Thripidae) on bean cultivars grown in the winter, rainy, and dry seasons in Brazil. Environmental Entomology, v. 44, n. 4, p. 1108-1115, 2015. http://dx.doi.org/10.1093/ee/nvv100.

Jesus, F. G. de et al. Interação de variedades, óleo de nim e inseticida no controle de Bemisia tabaci (Gennadius) biótipo B (Hemiptera: Aleyrodidae) e Caliothrips phaseoli (Hood) (Thysanoptera: Thripidae) na cultura do feijoeiro). Boletín de Sanidad Vegetal Plagas, v. 35, p. 491-500, 2009.
Lima, É. F. B. et al. New findings of thrips (Thysanoptera: Thripidae) on plants in Brazil. Florida Entomologist, v. 99, n. 1, p. 146-149, 2016. http://dx.doi.org/10.1653/024.099.0133.

Lima, É. F. B. et al. Thrips species (Insecta: Thysanoptera) associated to Fabaceae of agricultural importance in Cerrado and AmazonCaatinga ecotone from Brazilian Mid-North. Biota Neotropica, v. 13, n. 2, p. 283-289, 2013. http://dx.doi.org/10.1590/S167606032013000200027.

Lima, É. F. B. \& Zucchi, R. A. Thrips on fabaceous plants and weeds in an ecotone in northeastern Brazil. Ciência Rural, v. 46, n. 3, p. 393-398, 2016. http://dx.doi.org/10.1590/0103-8478cr20150613.

Loureiro, M. B. et al. Danos causados por insetos na germinação e no vigor de sementes de Apuleia leiocarpa Vog. Macbride. Agronomia, v. 38, n. 1, p. 105-109, 2004.

Molina-Arjona, C. et al. Caliothrips phaseoli (Thysanoptera: Thripidae) occurrence on Moringa oleifera (Brassicales: Moringaceae) and its predation of Tetranychus merganser (Acari: Tetranychidae). Journal of Entomological Science, v. 53, n. 1, p. 89-92, 2018. http://dx.doi.org/10.18474/JES17-76.1.

Rio Grande do Sul. Decreto n 52.109 de 1 de dezembro de 2014. Declara as espécies da flora nativa ameaçadas de extinção no Estado do Rio Grande do Sul. Diário Oficial do Estado, Porto Alegre, n. 233, 2 de dezembro de 2014. Available from: <http://www.al.rs.gov. br/filerepository/repLegis/arquivos/DEC\%2052.109.pdf>. Access on: 9 abr. 2018.

Santos, G. P. et al. Danos causados por insetos à sementes de garapa Apuleia leiocarpa (Leguminosae: Caesalpinoideae). Anais da Sociedade Entomológica do Brasil, v. 18, n. 2, p. 257-266, 1989.

Silva, A. G. A. et al. Ordem Thysanoptera, In: Quarto catálogo de insetos que vivem nas plantas do Brasil. Rio de Janeiro: Ministério da Agricultura, 1968. t 1. p. 18-33.

Sosa, M. R. et al. Ciclo de vida y reproducción de Caliothrips phaseoli (Thysanoptera: Thripidae) sobre Fabaceae y Solanaceae (Plantae) en condiciones de laboratório. Revista de la Sociedad Entomológica Argentina, v. 76, n. 3-4, p. 1-6, 2017. https://doi. org/10.25085/rsea.763401.

Souza, B. H. S. et al. Infestação de Empoasca kraemeri Ross \& Moore e Caliothrips phaseoli (Hood) em cultivares de feijoeiro na época da seca, em Selvíria-MS. EntomoBrasilis, v. 5, n. 3, p. 204-210, 2012.

Toldi, M. et al. Influence of various preys in soybean and the biological performance of the predatory mite Neoseiulus californicus (Phytoseiidae). Systematic and Applied Acarology, v. 21, n. 12, p. 1662-1669, 2016. http://dx.doi.org/10.11158/saa.21.12.7. 